\title{
Aplikasi paclobutrazol dan pelapisan lilin lebah terhadap mutu rimpang benih jahe merah (Zingiber officinale var. Rubrum) selama penyimpanan
}

\author{
(Application of paclobutrazol and beeswax coating towards the quality of red ginger \\ rhizomes during the storage)
}

\author{
M. A. Adipraja, S. Anwar dan F. Kusmiyati \\ Agroecotechnology, Faculty of Animal and Agricultural Sciences, Diponegoro University \\ Tembalang Campus, Semarang 50275 - Indonesia \\ Sendangmulyo, Tembalang, Semarang, Central java \\ Corresponding E-mail: alanadipraja@gmail.com
}

\begin{abstract}
Ginger is a plant that the rhizomes has a high economic value. The object of the research was to study the effect of paclobutrazol application and beeswax coating towards the quality of red ginger seed rhizomes during the storage. The experiment was conducted in April - Juli 2018 at Laboratory of Physiology and Plant Breeding, Faculty of Animal and Agricultural Sciences, Doponegoro University. The study was arranged in a complete factorial randomized design with three replications along with the first factor as the concentration of paclobutrazol, consisted of $0,500,1000$, and $1500 \mathrm{ppm}$. The second factor was the concentration of beeswax, consisted of $0,4,6$ and $8 \%$. Storage was conducted in storage conditions with a temperature of $28-30^{\circ} \mathrm{C}$ for three months. Seedling was conducted in seedling container for a month. The parameters observed were the number of sprouted seed rhizomes, hight of shoots, weight loss of seed rhizomes, and rhizome moisture content. Data were subjected to the analysis of variance test followed by Duncan's Multiple Range Test (DMRT). Based on the research, the result show that the treatment of paclobutrazol with a concentration $500 \mathrm{ppm}$ and the treatment of beeswax with a concentration $4 \%$ can inhibit shoot height, maintain the number of sprouted rhizomes, shrinkage of rhizome weight and rhizome moisture content until the end of storage period.
\end{abstract}

Keywords : red ginger, paclobutrazol, beeswax

\begin{abstract}
ABSTRAK
Jahe merupakan tanaman yang bagian rimpangnya memiliki nilai ekonomi yang tinggi. Penelitian ini bertujuan untuk mengkaji pengaruh aplikasi paclobutrazol dan pelapisan lilin lebah dalam mempertahankan mutu rimpang benih jahe merah selama penyimpanan. Penelitian dilaksanakan pada bulan April - Juli 2018 di Laboratorium Fisiologi dan Pemuliaan Tanaman, Fakultas Peternakan dan Pertanian, Universitas Diponegoro, Semarang. Penelitian ini merupakan percobaan faktorial $4 \mathrm{x} 4$ dengan 3 kali ulangan dengan dasar Rancangan Acak Lengkap (RAL). Faktor pertama adalah konsentrasi paclobutrazol dengan 4 taraf, terdiri atas 0, 500, 1000, $1500 \mathrm{ppm}$. Faktor kedua adalah konsentrasi lilin lebah dengan 4 taraf, terdiri atas $0,4,6$, dan $8 \%$. Penyimpanan dilakukan pada kondisi ruang simpan dengan suhu $28-30^{\circ} \mathrm{C}$ selama tiga bulan. Penyemaian dilakukan selama satu bulan setelah masa penyimpanan. Parameter yang diamati adalah jumlah rimpang bertunas, tinggi tunas, susut bobot rimpang dan kadar air rimpang. Data dianalisis menggunakan analisis ragam dan uji lanjut menggunakan Duncan Multiple Range Test (DMRT). Berdasarkan penelitian yang telah dilakukan diperoleh hasil bahwa perlakuan paclobutrazol dengan konsentrasi $500 \mathrm{ppm}$ dan perlakuan lilin lebah konsenrasi 4\% dapat menghambat tinggi tunas, mempertahankan jumlah rimpang bertunas, susut bobot rimpang dan kadar air rimpang hingga akhir masa simpan.
\end{abstract}

Kata kunci: jahe merah, paclobutrazol, lilin lebah. 


\section{PENDAHULUAN}

Jahe merah (Zingiber officinale var. Rubrum) merupakan salah satu produk hortikultura yang bagian rimpangnya memiliki nilai ekonomi penting di Indonesia. Rimpang jahe banyak digunakan sebagai bahan baku obat, jamu tradisional dan bumbu dapur. Luas area tanam jahe di Indonesia mencapai 6.053 ha, dengan rata rata kebutuhan benih per hektar sebesar $2000 \mathrm{~kg}$, maka dibutuhkan benih rimpang jahe sebesar 12.000 ton (Balittro, 2011).

Rimpang jahe berfungsi sebagai bahan perbanyakan tanaman atau benih. Perbanyakan menggunakan rimpang harus memenuhi ketentuan standar mutu benih. Bahan yang digunakan sebagai benih adalah rimpang tua yang berumur 89 bulan (Rukmana, 2006). Rimpang benih harus dalam kondisi baik. Ciri rimpang benih yang baik yaitu bentuknya tidak rusak, kulitnya tidak mengelupas, tidak terserang hama dan penyakit, serta terdapat minimal 2 bakal mata tunas (Hasanah dkk., 2004). Syarat rimpang benih siap tanam memiliki berat rimpang sebesar 40-60 gram untuk jahe putih besar dan 15-30 gram untuk jahe merah dan jahe putih, kadar air optimal sebesar $70 \%$ dan daya berkecambah $80 \%$ (BSN, 2006)

Seiring dengan berkembangnya industri obat herbal, permintaan terhadap jahe juga meningkat. Penyediaan rimpang benih jahe merah yang bermutu dan dalam jumlah yang mencukupi merupakan kendala yang dihadapi petani di Indonesia. Rimpang benih jahe sebagai materi perbanyakan bersifat mudah bertunas saat penyimpanan dan dapat menurunkan kualitasnya (Irawan dan Iwanuddin, 2015). Salah satu upaya untuk menekan pertumbuhan tunas pada rimpang jahe yaitu menggunakan inhibitor paclobutrazol. Paclobutrazol bekerja pada bagian meristem tumbuhan dengan cara menghambat biosintesa giberelin (Winten, 2009). Terhambatanya biosintesa giberelin mengakibatkan pertumbuhan dan pemanjangan sel menjadi lambat.

Pelapisan rimpang dengan lilin lebah juga merupakan salah satu upaya untuk mempertahankan kadar air rimpang dan mutu rimpang. Lilin merupakan ester dari asam lemak berantai panjang dengan alkohol monohidrat berantai panjang atau sterol (Pangestuti dan Sugiyatno, 2004). Fugsi utama pelapisan lilin menggunakan lilin lebah yaitu mencegah susut bobot yang tinggi, menghambat pelunakan dan menurunkan laju respirasi dan transpirasi dengan membentuk halangan bagi pertukaran udara (Purwoko dan Suryana, 2000).

Penyimpanan rimpang benih jahe merah dapat dilakukan di dalam ruangan maupun di luar ruangan. Kondisi ruang penyimpanan yang ideal adalah penyimpanan di suhu rendah $\left(15^{\circ} \mathrm{C}\right)$, kelembaban udara $75-80 \%$, cukup cahaya dan terhindar dari percikan air hujan (Sukarman dan Seswita, 2012). Namun, penyimpanan pada suhu rendah memerlukan biaya yang lebih untuk petani. Tempat penyimpanan secara komersial dilakukan dengan cara menyimpan rimpang benih di rak-rak kayu, keranjang bambu atau karung. Ruang yang digunakan berventilasi dengan suhu $20-25^{\circ} \mathrm{C}$ dan kelembaban udara 75-80\%. (Emiati dan Sukarman, 2005). Penyimpanan selama 3-4 bulan tidak memerlukan perlakuan khusus, jika memenuhi syarat ketinggian 600 meter di atas permukaan laut (mdpl) dengan suhu rata-rata $25^{\circ} \mathrm{C}$ (Sukarman dkk., 2008). Semakin tinggi daerah dan semakin rendah suhu yang digunakan untuk menyimpan rimpang, semakin panjang daya simpannya.

Beberapa penelitian menggunakan paclobutrazol sebagai zat penghambat diantaranya yaitu aplikasi paclobutrazol 1500 ppm pada jahe putih besar belum mampu menghambat susut bobot rimpang benih hingga 3 bulan simpan, pada kondisi suhu ruang $26-28^{\circ} \mathrm{C}$ (Rusmin, dkk. 2015). Aplikasi paclobutrazul pada kencur juga meningkatkan bobot kering rimpang dan kadar minyak yang lebih tinggi pada dosis paclobutrazol 250 ppm (Rosita dkk., 1996). Beberapa penelitian pelapisan lilin lebah diantaranya yaitu kombinasi pelapisan lilin lebah 4\% dan paclobutrazol pada dosis 1500 ppm suhu $20-22^{\circ} \mathrm{C}$ mampu menekan presentase rimpang bertunas jahe putih besar selama 3 bulan (Rusmin dkk., 2015).

Tujuan penelitian ini adalah mengkaji pengaruh aplikasi paclobutrazol dan pelapisan lilin lebah dalam mempertahankan mutu rimpang benih jahe merah selama penyimpanan.

\section{MATERI DAN METODE}

Penelitian ini dilaksanakan pada bulan April - Juli 2018 di Laboratorium Fisiologi dan 
Tabel 1. Jumlah rimpang bertunas jahe merah di akhir masa simpan.

\begin{tabular}{cccccc}
\hline \hline Konsentrasi & \multicolumn{4}{c}{ Konsentrasi Lilin Lebah (\%) } & Rata-rata \\
\cline { 2 - 6 } Paclobutrazol (ppm) & 0 & 4 & 6 & 8 & \\
\hline 0 & 9,00 & 4,00 & 5,00 & 4,00 & 5,50 \\
500 & 8,33 & 4,00 & 3,67 & 3,33 & 4,83 \\
1000 & 7,33 & 4,67 & 4,00 & 4,33 & 5,08 \\
1500 & 7,67 & 4,33 & 3,00 & 3,67 & 4,67 \\
\hline Rata-rata & $8,08^{\mathrm{a}}$ & $4,25^{\mathrm{b}}$ & $3,92^{\mathrm{b}}$ & $3,83^{\mathrm{b}}$ & \\
\hline
\end{tabular}

Keterangan: Superskrip yang berbeda pada baris rata-rata menunjukkan perbedaan yang nyata $(\mathrm{P}<0,05)$

Pemuliaan Tanaman, Fakultas Peternakan dan Pertanian, Universitas Diponegoro, Semarang.

\section{Materi}

Bahan yang digunakan dalam penelitian ini adalah rimpang jahe merah (Zingiber officinale var. Rubrum) umur 9 bulan yang didapatkan dari daerah Kabupaten Sleman, Yogyakarta,, inhibitor paclobutrazol dan bahan pelapis lilin lebah.

\section{Metode}

Tahapan penelitian meliputi pembuatan larutan paclobutrazol, pembuatan emulsi lilin lebah, pelapisan rimpang dengan paclobutrazol dan lilin lebah, penyimpanan rimpang dan persemaian.

Paclobutrazol dibuat dengan konsentrasi 500, 1000 dan 1500 ppm. Emulsi lilin lebah dibuat dengan konsentrasi 4,6 dan $8 \%$. Pembuatan emulsi lilin dengan bahan lilin lebah, pengemulsi trietanolamin (TEA) dan asam oleat. Lilin yang padat dipanaskan di panci hingga mencair. Rumus perbandingan dalam pembuatan emulsi lilin lebah yaitu lilin : TEA : asam oleat dengan perbandingan volume $6: 2: 1$ (Pangestuti dan Sugiyatno, 2004)

Rimpang yang sudah dibersihkan dicelupkan ke dalam masing-masing larutan paclobutrazol sesuai perlakuan selama 2 jam. Rimpang ditiriskan dan dikeringanginkan selama satu hari. Rimpang yang sudah dikeringkan dilapisi dengan lilin lebah dengan cara dicelupkan selama 30 menit, kemudian ditiriskan dan dikering anginkan selama dua hari. Penyimpanan dilakukan dengan cara meletakkan rimpang yang sudah diberi perlakuan ke rak kayu selama tiga bulan. Penyemaian dilakukan dengan cara menghamparkan rimpang pada media arang sekam selama 1 bulan setelah tiga bulan masa simpan.

Rimpang benih jahe merah disimpan pada kondisi suhu ruang $\left(28-30^{\circ} \mathrm{C}\right)$. Parameter yang diamati adalah jumlah rimpang bertunas, tinggi tunas selama penyimpanan, jumlah rimpang keriput dan susut bobot rimpang. Pengamatan jumlah rimpang bertunas dilakukan pada akhir periode simpan. Pengamatan tinggi tunas penyimpanan dilakukan pada akhir periode simpan. Pengamatan terhadap susut bobot rimpang jahe merah dengan cara rimpang jahe yang belum diberi perlakuan ditimbang berat awalnya, kemudian rimpang diberi perlakuan dan ditimbang berat akhirnya. Penyusutan bobot dihitung berdasarkan selisih bobot benih sebelum disimpan dengan bobot setelah disimpan dibagi bobot sebelum disimpan. Presentase susut bobot rimpang dapat diperoleh dengan rumus:

Susut Bobot $(\%)=\frac{A-B}{A} \times 100 \%$

Keterangan: $\mathrm{A}=$ Berat bahan awal penyimpanan $(\mathrm{g})$

$\mathrm{B}=$ Berat bahan setelah simpan $(\mathrm{g})$

Pengukuran kadar air rimpang dilakukan pada empat bulan setelah simpan yang artinya tiga bulan simpan dan satu bulan persemaian. Bobot sampel ditimbang sebelum dan sesudah dilakukan pengovenan. Rimpang dikeringkan, diiris-iris dan dioven sampai bobot konstan pada suhu $70^{\circ} \mathrm{C}$ selama 72 jam. Perhitungan kadar air yaitu dengan rumus: 
Tabel 2. Tinggi tunas rimpang jahe merah di akhir masa simpan

\begin{tabular}{|c|c|c|c|c|c|}
\hline \multirow{2}{*}{$\begin{array}{c}\text { Konsentrasi } \\
\text { Paclobutrazol (ppm) }\end{array}$} & \multicolumn{4}{|c|}{ Konsentrasi Lilin Lebah (\%) } & \multirow{2}{*}{ Rata-rata } \\
\hline & 0 & 4 & 6 & 8 & \\
\hline & \multicolumn{4}{|c|}{ 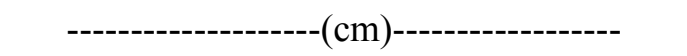 } & \\
\hline 0 & 0,60 & 0,44 & 0,45 & 0,46 & $0,48^{\mathrm{a}}$ \\
\hline 500 & 0,55 & 0,44 & 0,29 & 0,39 & $0,41^{\mathrm{ab}}$ \\
\hline 1000 & 0,46 & 0,40 & 0,41 & 0,32 & $0,39^{\mathrm{b}}$ \\
\hline 1500 & 0,41 & 0,26 & 0,25 & 0,35 & $0,31^{\mathrm{c}}$ \\
\hline Rata-rata & $0,50^{\mathrm{a}}$ & $0,38^{b}$ & $0,35^{\mathrm{b}}$ & $0,38^{\mathrm{b}}$ & \\
\hline
\end{tabular}

$\mathrm{Ka}=\frac{\mathrm{BB}-\mathrm{BK}}{\mathrm{BB}} \times 100 \%$

Keterangan: $\mathrm{BB}=$ bobot sampel awal $(\mathrm{g})$

$\mathrm{BK}=$ bobot sampel akhir $(\mathrm{g})$

\section{Rancangan percobaan dan analisis data}

Penelitian ini merupakan percobaan faktorial $4 \times 4$ diulang sebanyak 3 kali ulangan dengan dasar Rancangan Acak Lengkap (RAL). Analisis data menggunakan analisis ragam ANOVA untuk mengetahui pengaruh perlakuan dan jika terdapat pengaruh dilanjutkan dengan uji DMRT (Duncan Multiple Range Test) dengan taraf 5\% untuk mengevaluasi perbedaan antar perlakuan.

\section{HASIL DAN PEMBAHASAN}

\section{Jumlah Rimpang Bertunas}

Hasil analisis ragam menunjukkan bahwa perlakuan lilin lebah dengan konsentrasi yang berbeda memberikan pengaruh nyata $(\mathrm{P}<0,05)$ pada parameter jumlah rimpang bertunas, sedangkan perlakuan paclobutrazol dan interaksi paclobutrazol dengan lilin lebah tidak berpengaruh nyata pada parameter jumlah rimpang bertunas. Hasil uji Duncan parameter jumlah rimpang bertunas jahe merah di akhir masa simpan disajikan pada Tabel 1.

Berdasarkan Tabel 1. jumlah rimpang yang bertunas pada perlakuan tanpa lilin lebah nyata lebih tinggi dibanding perlakuan lilin lebah yang lain. Perlakuan lilin lebah konsentrasi 4, 6 dan 8\% nyata menekan jumlah rimpang bertunas. Hal tersebut berkaitan dengan fungsi lilin lebah yang memberi lapisan luar rimpang sehingga menghalangi oksigen yang masuk ke rimpang. Tumbuhan dalam siklus hidupnya memerlukan energi untuk tumbuh yang didapatkan dari proses respirasi. Adanya respirasi pada tumbuhan akan menunjang pembelahan sel pada jaringan meristem. Raharjo (2011) menyatakan bahwa pelapisan lilin mengakibatkan respirasi menjadi terhambat yang juga berpengaruh terhadap pemanjangan sel. Rendahnya proses respirasi dan metabolisme yang merombak pati menjadi gula sederhana mengakibatkan jumlah rimpang yang bertunas menjadi rendah. Lapisan lilin menghambat pertukaran oksigen saat rimpang melakukan respirasi. Respirasi yang terhambat juga akan menghambat laju pertumbuhan tunas. Hal ini sesuai dengan pendapat Raharjo (2011) bahwa rendahnya proses respirasi dan metabolisme yang merombak pati menjadi gula sederhana mengakibatkan jumlah rimpang yang bertunas menjadi rendah.

Jumlah rimpang bertunas pada perlakuan lilin lebah konsentrasi $0 \%$ adalah 8,08 , sedangkan rimpang pada perlakuan pelapisan lilin lebah memiliki jumlah rimpang bertunas yang lebih rendah dari kontrol yaitu 4,25, 3,92 dan 3,83. Sukarman dan Seswita (2012) menyatakan bahwa pertumbuhan tunas mungkin dapat dihambat dengan menghambat laju respirasinya menggunakan penyimpanan dalam kemasan dengan kadar oksigen yang terbatas.

Hasil pada penelitian ini menunjukkan 
Tabel 3. Susut bobot rimpang di akhir masa simpan

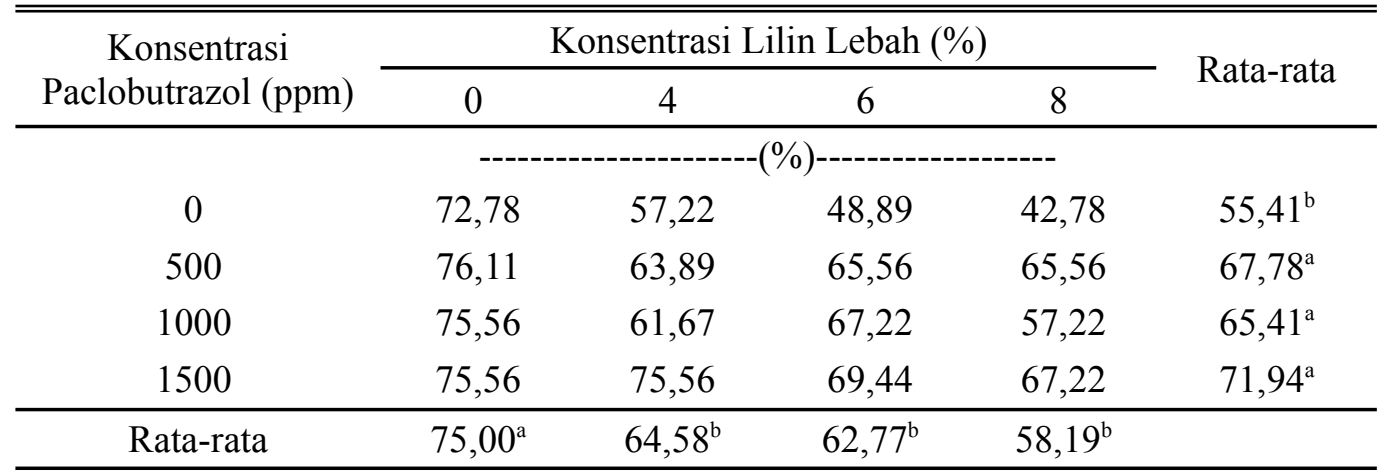

Keterangan: Superskrip yang berbeda pada baris rata-rata dan kolom rata-rata menunjukkan perbedaan yang nyata $(\mathrm{P}<0,05)$

bahwa parameter jumlah rimpang bertunas dipengaruhi oleh lokasi simpan dan suhu rahian lokasi tersebut. Hal ini diperkuat oleh hasil penelitian Sukarman dan Seswita (2012) bahwa benih jahe yang disimpan di Kp. Gunung Putri dengan suhu harian $19,2^{\circ} \mathrm{C}$ dapat menekan jumlah rimpang bertunas selama penyimpanan. Rendahnya suhu di sekitar penyimpanan rimpang jahe mengakibatkan rendahnya respirasi dan proses metabolisme yang merombak pati menjadi gula sederhana, sehingga jumlah ripang yang bertunas menjadi rendah. Berdasarkan hasil pada tabel 1. bahwa jumlah tunas masih layak untuk dijadikan bibit. Menurut BSN (2006) jumlah mata tunas yang memenuhi syarat yaitu lebih dari 2 mata tunas.

\section{Tinggi tunas}

Hasil analisis ragam menunjukkan bahwa perlakuan lilin lebah dan perlakuan paclobutrazol dengan konsentrasi yang berbeda memberikan pengaruh nyata $(\mathrm{P}<0,05)$ pada parameter tinggi tunas, sedangkan perlakuan interaksi paclobutrazol dengan lilin lebah tidak berpengaruh nyata pada parameter tinggi tunas. Hasil uji Duncan parameter tinggi tunas rimpang benih jahe merah disajikan pada Tabel 2.

Berdasarkan Tabel 2. tinggi tunas pada perlakuan tanpa paclobutazol nyata lebih tinggi dibanding perlakuan paclobutrazol. Perlakuan paclobutazol 500, 1000 dan 1500 ppm nyata menekan tinggi tunas pada masa simpan. Paclobutrazol merupakan zat pengatur tumbuh yang berfungsi menghambat pertumbuhan.
Rimpang yang diberi perlakuan paclobutrazol pertumbuhan tunasnya akan terhambat. Hal ini sesuai dengan pendapat Winten (2009) yang menyatakan bahwa paclobutrazol bekerja pada bagian meristem tumbuhan dengan cara menghambat biosintesa giberelin. Paclobutrazol merupakan zat pengatur tumbuh yang berfungsi menghambat pertumbuhan. Terhambatanya biosintesa giberelin mengakibatkan pertumbuhan dan pemanjangan sel menjadi lambat, namun hal ini tidak menyebabkan keracunan pada sel (Berova dkk., 2002).

Perlakuan paclobutrazol hanya berpengaruh terhadap tinggi tunas pada satu bulan setelah simpan. Menurut Rusmin dkk. (2015) menyatakan bahwa suhu ruang rimpan memiliki pengaruh terhadap panjang tunas. Suhu ruang simpan 20$22^{\circ} \mathrm{C}$ mampu menekan tinggi tunas tidak lebih dari $1 \mathrm{~cm}$ hingga 4 bulan simpan. Suhu ruang simpan yang rendah diduga dapat mempertahankan dormansi tunas. Peningkatan konsentrasi paclobutrazol menyebabkan tinggi tunas semakin dapat ditekan. Hal ini sesuai dengan pendapat Harahap dkk. (1991) bahwa tinggi tunas dapat semakin ditekan dengan cara menambah konsentrasi paclobutrazol. Pemberian paclobutrazol pada rimpang diduga mengakibatkan kadar giberelin dalam rimpang menjadi rendah, akibatnya dormansi dapat dipertahankan.

Tinggi tunas pada rimpang tanpa perlakuan dan pada rimpang yang diberi perlakuan menunjukkan bahwa masih sesuai syarat mutu rimpang yang baik. Hal ini sesuai dengan 
Tabel 4. Kadar Air Rimpang Benih Jahe Merah

\begin{tabular}{cccccc}
\hline \hline \multirow{2}{*}{$\begin{array}{c}\text { Konsentrasi } \\
\text { Paclobutrazol (ppm) }\end{array}$} & \multicolumn{4}{c}{ Konsentrasi Lilin Lebah (\%) } & \multirow{2}{*}{ Rata-rata } \\
\cline { 2 - 4 } 0 & 0 & 4 & 6 & 8 & \\
\hline & $--------------(\%)$ & ----------- & \\
500 & 80,00 & 85,63 & 86,34 & 88,22 & 85,04 \\
1000 & 78,90 & 85,17 & 89,10 & 84,04 & 84,30 \\
1500 & 76,62 & 82,46 & 83,16 & 85,75 & 81,99 \\
\hline Rata-rata & 73,56 & 79,80 & 84,00 & 85,16 & 80,63 \\
\hline Keterangan: Superskrip yang berbeda pada baris rata-rata dan kolom rata-rata menunjukkan perbedaan yang nyata $(\mathrm{P}<0,05)$
\end{tabular}

pendapat Rostiana dkk. (2012) bahwa tunas yang tumbuh melebihi $1 \mathrm{~cm}$ saat masa penyimpanan dapat mempersulit proses pengemasan dan pengiriman rimpang benih hingga ke luar kota. Pertumbuhan tunas pada saat penyimpanan juga dapat mengurangi kadar minyak atsiri, karena sebagian nutrisi yang disimpan dalam rimpang digunakan untuk pertumbuhan tunas.

Pelapisan lilin lebah akan efektif bila diaplikasikan pada suhu rendah. Hal ini sesuai dengan penelitian Rusmin dkk. (2015) yang menyatakan bahwa rimpang jahe putih besar yang dilapisi lilin lebah konsentrasi $4 \%$ pada suhu ruang simpan yang tinggi $\left(26-28^{\circ} \mathrm{C}\right)$ kurang efektif. Tingginya suhu ruang akan mengakibatkan aktifitas fisiologis seperti penggunaan energi pada rimpang meningkat. Energi atau panas yang timbul mengakibatkan lapisan lilin yang tipis menjadi rusak sehingga penguapan menjadi tinggi.

\section{Susut Bobot Rimpang}

Hasil analisis ragam menunjukkan bahwa perlakuan faktor tunggal lilin lebah dan perlakuan paclobutrazol dengan konsentrasi yang berbeda memberikan pengaruh nyata $(\mathrm{P}<0,05)$ pada parameter susut bobot rimpang, sedangkan perlakuan interaksi paclobutrazol dengan lilin lebah tidak berpengaruh nyata pada parameter susut bobot rimpang. Hasil uji Duncan parameter susut bobot rimpang benih jahe merah disajikan pada Tabel 3.

Berdasarkan Tabel 3. susut bobot rimpang dipengaruhi oleh faktor tunggal perlakuan paclobutrazol maupun faktor lilin lebah. Perlakuan paclobutrazol pada berbagai konsentrasi susut bobotnya lebih tinggi dibandingkan kontrol. Perlakuan paclobutrazol pada suhu tinggi belum mampu menekan susut bobot rimpang jahe merah. Perlauan kontrol memiliki nilai susut bobot yang lebih rendah dibanding perlakuan paclobutrazol pada berbagai konsentrasi. Hal ini diperkuat oleh pendapat Sukarman dkk. (2008) menyatakan bahwa untuk menyimpan rimpang benih jahe putih besar dalam waktu yang pendek tidak memerlukan perlakuan khusus. Hal ini diperkuat oleh pendapat Rusmin dkk. (2015) bahwa pemberian paclobutrazol pada suhu tinggi justru berdampak negatif bagi rimpang.

Jahe merah memiliki nilai susut bobot yang lebih tinggi daripada jahe putih besar maupun jahe putih kecil. Hal ini dikarenakan bentuk rimpang jahe merah yang lebih kecil dibandingkan jahe putih besar dan jahe putih kecil. Hal ini sesuai dengan pendapat Sukarman dan Melati (2008) bahwa kandungan air jahe merah lebih banyak menguap yang menyebabkan lebih tingginya susut bobot rimpang benih.

Perlakuan tanpa lilin lebah nyata lebih tinggi dibanding perlakuan lilin lebah dengan berbagai konsentrasi. Lilin lebah berfungsi sebagai pelapis rimpang yang dapat menghambat penguapan air yang berlebih. Hal ini sesuai dengan pendapat Purwoko dan Suryana (2000) bahwa fugsi utama pelapisan lilin menggunakan lilin lebah yaitu mencegah susutu bobot yang tinggi, menghambat pelunakan dan menurunkan laju respirasi dan transpirasi dengan membentuk halangan bagi pertukaran udara. Susut bobot pada perlakuan lilin 
lebah masih diatas 50\%. Hal ini diakibatkan karena suhu ruang simpan yang tinggi. Sukarman dan Seswita (2012) menyatakan bahwa rimpang jahe yang dilapisi lilin pada berbagai konsentrasi belum mampu menekan penguapan air pada suhu yang tinggi.

Pelapisan lilin lebah lebih efektif jika ruang simpan memiliki suhu yang rendah. Hal ini sesuai dengan pendapat Hassan dkk. (2014) bahwa pelapisan lilin lebah $12 \%$ pada suhu ruang simpan $5^{\circ} \mathrm{C}$ mampu menekan susut bobot jeruk Siam Banjar 17-24\%. Dhyan dkk. (2014) menyatakan bahwa pelapisan lilin $4 \%$ pada suhu $5^{\circ} \mathrm{C}$ mampu menekan susut bobot jambu biji. Marlina dkk (2014) menyatakan bahwa pelapisan lilin pada suhu $8^{\circ} \mathrm{C}$ mampu menekan susut bobot manggis. Pelapisan lilin lebah pada suhu rendah dapat menekan respirasi rimpang selama masa simpan sehingga susut bobotnya dapat ditekan.

\section{Kadar Air Rimpang}

Hasil analisis ragam menunjukkan bahwa perlakuan faktor tunggal lilin lebah dengan konsentrasi yang berbeda memberikan pengaruh nyata $(\mathrm{P}<0,05)$ pada parameter kadar air rimpang, sedangkan perlakuan paclobutrazol dan interaksi paclobutrazol dengan lilin lebah tidak berpengaruh nyata pada parameter susut bobot rimpang. Hasil uji Duncan parameter kadar air rimpang benih jahe merah disajikan pada tabel 4.

Berdasarkan Tabel 4. kadar air rimpang pada perlakuan tanpa lilin lebah yaitu $77,27 \%$ lebih rendah dibanding perlakuan lilin lebah pada berbagai konsentrasi. Kadar air rimpang pada perlakuan lilin lebah nilainya $>70 \%$, artinya kadar air rimpang masih baik selama 3 bulan penyimpanan dengan perlakuan berbagai konsentrasi lilin lebah. Kadar air rimpang benih jahe merah yang siap tanam yaitu $>70 \%$ Menurut Badan Standarisasi Nasional (2006).

Kadar air yang terlalu tinggi akan menyebabkan rimpang benih mudah berkecambah sebelum ditanam. Benih yang kadar airnya terlalu rendah justru akan menyebabkan kerusakan pada embrio. Hal ini diperkuat oleh pendapat Priandoko (2011) bahwa benih dengan kadar air yang terlalu tinggi akan meningkatkan aktifitas respirasi pada saat penyimpanan yang menyebabkan habisnya cadangan makanan dalam benih. Lilin lebah memiliki fungsi menciptakan kondisi suhu dan kelembaban tertentu di sekitar rimpang yang dilapisi. Hal ini sesuai dengan Marlina (2014) bahwa pelapisan lilin lebah membentuk lapisan semi permiabel sehingga mampu memodifikasi atmosfer internal pada rimpang yang dilapisi. Adanya lapisan lilin menyebabkan respirasi menjadi menurun.

Kadar air rimpang pada perlakuan paclobutrazol meskipun tidak memiliki pengaruh nyata, namun kadar air rimpang masih memenuhi standar yang ditetapkan BSN (2006) yaitu $>70 \%$. Rimpang benih tanpa perlakuan paclobutrazol masih memiliki kadar air yang tinggi saat disimpan selama tiga bulan. Hal ini sesuai dengan pendapat Sukarman dan Melati (2011) bahwa penyimpanan rimpang jahe tidak memerlukan perlakuan khusus jika disimpan pada kondisi yang ideal selama 3 bulan simpan. Kondisi ruang simpan yang ideal yaitu di datran menengah hingga tinggi (600-1400 $\mathrm{m} \mathrm{dpl}$ ) dan suhu harian rata-rata $22^{\circ} \mathrm{C}$.

\section{KESIMPULAN}

Berdasarkan penelitian yang telah dilakukan dapat disimpulkan bahwa perlakuan paclobutrazol dengan konsentrasi $500 \mathrm{ppm}$ dan perlakuan lilin lebah konsenrasi 4\% dapat menghambat tinggi tunas, mempertahankan jumlah rimpang bertunas, susut bobot rimpang dan kadar air rimpang hingga akhir masa simpan.

\section{DAFTAR PUSTAKA}

Badan Standarisasi Nasional. 2006. SNI 01-71532006 Benih Jahe (Zingiber officinale L.) kelas benih pokok (BP) dan kelas benih sebar (BR). Badan Standarisasi Nasional. Jakarta.

Balittro. 2011. Produksi Benih Sumber Tanaman Obat dan Aromatik. Laporan Balittro. Bogor.

Dhyan S.C., S.H. Sumarlan, dan B Susilo. 2014. Pengaruh pelapisan lilin lebah dan suhu penyimpanan terhadap kualitas buah jambu biji (Psidium guajava L.) J. Bioproses Komoditas Tropis. 2 (1): 79-90.

Emiati dan Sukarman. 2005. Feasibility study on ginger seed production through intercropping 
with secondary and vegetable crops. J. Gakuryoku (11): 44-47

Ermiati. 2010. Analisa kelayakan dan kendala pengembangan usaha tani jahe putih kecil di Kabupaten Sumedang, studi kasus Kecamatan Cimalaka. Bul. Littro 21(1) 86-92.

Harahap, A.H., Rosita S.M.D. dan G. Pangabean. 1991. Pengaruh waktu penyimpanan serta perendaman dengan paclobutrazol terhadap pertumbuhan tunas rimpang jahe (Zingiber officinale Rosc.). Bul. Littro 6 (2): 96-100

Hasan, Z. H., S. Lesmayati, R. Qomariyah dan A. Hasbianto. 2014. Effect of wax coating application and storage temperatures on the quality of Tangerine Citrus (Citrus reticulata) var Siam Banjar. International Food Research Journal. 21 (2): 641-648.

Irawan, A., dan Iwanuddin. 2015. Efektifitas penggunaan bahan penghambat tumbuh pada bibit Shorea assamica Dyer di persemaian. J. Wasian 2 (1): 41-46.

Marlina, L., Y. A. Purwanto dan U. Ahmad. 2014. Aplikasi pelapisan kitosan dan lilin lebah untuk meningkatkan umur simpan salak pondoh. J. Keteknikan Pertanian 2 (1): 65 72.

Pangestuti, R., dan A. Sugiyanto. 2004. Pelilinan pada buah jeruk. Loka Penelitian Tanaman Jeruk dan Hortikultura (1): 1-2

Priandoko, S. C. 2011. Pengujian Benih di Laboratorium. Dinas Pertanian Provinsi DIY. Yogyakarta.

Purwoko, B.S., dan K. Suryana. 2000. Efek suhu simpan dan pelapis terhadap perubahan kualitas buah pisang cavendish. Bul. Agron 28 (3): 77-84.
Raharjo, M. 2011. Pengaruh perlakuan benih dan aplikasi pertisida sintetik dan nabati terhadap produksi rimpang benih jahe. Bul. Littro 22 : $157-165$

Rostiana, O., Nurliani B., dan Mono R. 2012. Standar Prosedur Operasional Budidaya Jahe, Bogor: Balai Penelitian Tanaman Rempah dan Obat.

Rusmin, D., M.R. Suhartanto, dan S. Ilyas. 2015. Mutu fisiologis jahe putih besar selama penyimpanan dengan pelapisan lilin dan aplikasi paclobutrazol. Bul. Littro 26 (1): 3546

Sorce, C., A. Piaggesi, N. Cecarlli, dan R. Lorenzi. 1996. Rale and metabolism of absicic acid in potato tuber dormancy and sprouting. J. Plant Physiol 149: 548-552.

Sukarman. D. Rusmin dan Melati. 2008. Pengaruh lokasi produksi dan lama penyimpanan terhadap mutu benih jahe (Zingiber officinale L.). J. Littri 14 (3): 119 -124

Sukarman dan Melati. 2011. Prosesing dan Penyimpanan Benih Jahe (Zingiber officinale Rosc). Balai Penelitian Tanaman Obat dan Aromatik. Bogor.

Sukarman dan Melati. 2011. Produksi benih Jahe (Zingiber officinale Rosc.) Sehat. Balai Penelitian Tanaman Obat dan Aromatik. Bogor.

Sukarman dan D. Seswita. 2012. Pengaruh lokasi penyimpanan dan pelapisan (coating) benih dengan pestisida nabati terhadap mutu benih rimpang jahe. Bul. Littro 23 (1): 1-10

Winten, K.T.I. 2009. Zat pengatur tumbuh dan perannya dalam budidaya tanaman. Majalah Ilmiah Universitas Tabana 6 (1): 49-58 